\title{
Rethinking the role of sheep in the local development of Patagonia, Argentina
}

\author{
Fernando Coronato $^{1}$ Enzo Fasioli $^{2}$ Alejandro Schweitzer ${ }^{3}$ \\ Jean-François Tourrand ${ }^{4 *}$
}

\section{Keywords}

Sheep, land use, rangeland, desertification, colonization ability, Argentina

Accepted: 21 December 2014; Published: 25 March 2016

\begin{abstract}
Summary
Patagonia has the world's southernmost rangelands, which are among the last to be dedicated to farming. Commercial sheep herding in the area only started 100-120 years ago and thrived until the 1930 world crisis, triggering the rapid colonization of grasslands of diverse productivity. Besides this agronomic diversity, natural hazards such as droughts or heavy snowfalls associated with the vagaries of economic policies have always made sheep farming in Patagonia a very uncertain activity. Consequently, sheep gradually lost ground as the leading socio-economic activity to oil and gas production, fishing, and lately tourism. Things worsened during the last quarter of the 20th century to the point where the contribution of agriculture to the regional gross domestic product is today less than $5 \%$. However, sheep farming is the only activity that ensures the occupation, even sparse, of the region and, owing to its pioneer character, it still plays a major part in Patagonian identity. Thus, we believe that mutton and wool production still have a role to play in the future of the region, although we argue that this issue would take the form of one of three scenarios that we termed "laissez-faire", "park" and "sheep" according to the intensity of the decision involved and the funding required. The three scenarios could eventually coexist but long-term sustainability would have the last word.
\end{abstract}

- How to cite this article: Coronato F., Fasioli E., Schweitzer A., Tourrand J.-F., 2015. Rethinking the role of sheep in the local development of Patagonia, Argentina. Rev. Elev. Med. Vet. Pays Trop., 68 (2-3): 129-133

\section{INTRODUCTION}

Patagonia is located between $40^{\circ}$ and $55^{\circ} \mathrm{S}$, in the westerlies belt, and presents two sharply contrasted faces on either side of the Andes. On the windward side, Chilean Patagonia is a narrow strip of snow-capped mountains, lakes and fjords, with a windy, rainy, and cool climate. On the leeward side, Argentinean Patagonia consists of vast plateaus interspersed with fluvio-glacial valleys; climate is also windy and cool, yet dry because of the rain-shadow effect of the Andean range; annual rainfall exceeds $200 \mathrm{~mm}$ only in some favorable locations.

Until the 19th century, because of its austere environment, Patagonia stayed clear of the colonial ambitions of the Spanish and

\footnotetext{
1. CENPAT-CONICET, Puerto Madryn, Chubut, Argentina.

2. UNPat, Río Turbio, Santa Cruz, Argentina.

3. CONICET-UNPat, Río Gallegos, Santa Cruz, Argentina.

4. CIRAD, UPR Green, TA 179/04, avenue Agropolis, 34398 Montpellier Cedex 5, France.

* Corresponding author

Tel.: +33 (0)4 676157 79; Email: tourrand@aol.com
}

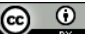

https://creativecommons.org/licenses/by/4.0/
British empires, although imperial attention was paid to the Falklands and the Strait of Magellan in order to control the transoceanic trade. Once the South American colonies gained independence, the world powers focused on the Argentine pampas and central Chile because of their agropastoral potential. Since 1879 , the "Conquest of the Desert " by the Argentine army has appeared to be as much caused by the will of the young Republic to control its national territory as by the British interest to expand sheep farming for the benefit of wool companies already well established in the Falklands and Buenos Aires. A similar process took place in Chilean Patagonia, in Magellan area. The expansion of sheep was carried out at the expense of several thousands of Native Americans, who were killed, reduced to servitude, or scattered on the margins of the "new order". Patagonia was thus free to be occupied by settlers of European ancestry coming from the Falklands, Buenos Aires, or central Chile, for the greater benefit of British, Flemish or German wool companies (Nouzeilles, 1999; Cibils and Borrelli, 2005).

Sheep numbers peaked in the 1950s when about 22 million animals were recorded. From then on overgrazing became evident, reducing the productive capacity of these rangelands. This, together with difficulties in commercializing wool and meat, led to the adoption of non-sustainable ecological and economic dynamics 
during the recent decades (Ares, 2006) as evidenced by a national stock as low as 10 million sheep in the 1990s.

Depending on the time and region, sheep farming has been carried out very extensively in plots ranging from 10,000 to 30,000 hectares, which would support flocks of 2,000 to 15,000 sheep. These figures were much higher in company-owned ranches. This model was mostly based on those that had built the wealth of the pampas and the Falklands; it only differed in the larger size of the fields.

However, less than a century after the beginning of pastoral colonization, it has transformed much of the vast steppes of Patagonia in desert-like areas, especially in its central and eastern parts (i.e. regions with lesser rainfall), to the point that sheep grazing ended in many ranches (between one third and two thirds depending on the area). Some farms have managed to survive with a carrying capacity as low as one sheep per 8-12 hectares (Del Valle et al., 1997).

Other authors (Defossé and Robberecht, 1987; Cibils and Borrelli, 2005) argue that the combination of overgrazing and firewood gathering from shrub land (even if the latter was necessary because of the harsh climate) dramatically reduced the shrub and grass cover, leaving the soil unprotected against weather exposure and thus triggering the negative effect of desertification. However, sheep farming continues to prosper in ranches located along the Andean piedmont and in the far south around the strait, since these wetter regions are more productive. Additionally, some farms crossed by a watercourse can irrigate forage crops, mainly alfalfa hay, to supplement their flocks and cope with drought.

At first, the sheep introduced into Patagonia had been nonspecific crossbred, and named after their origin, i.e. Pampa for those that originated from the North and Malvinera for those from the Falklands. Later on, South Patagonia favored the dual-purpose Corriedale breed, whereas the North preferred the Merinos and specialized in wool production. At the beginning wool and mutton (processed in coastal freezing plants) were directly exported to Europe, but after World War II the Argentine meat market started to decline, whereas the wool market (and consequently Merinos) grew. The process is still going on and the Corriedale-Merinos border continues pushing southward (Figure 1).

Desertification in Patagonia would then be a direct consequence of the unwise application in arid rangelands of a productive model designed and adapted to wetter ecosystems such as the pampas or the Falklands. The original overestimation of the carrying capacity of these rangelands led to their overstocking during a century and is considered as the main cause of its current desertification (Golluscio et al., 1998). Since the 1950-1960s, this compelling environmental context has been aggravated by the weakening of the sheep industry in Patagonia, comprising both wool and meat production, and had been negatively influenced by the vagaries of Argentine politics and by globalization, especially from the many variations in the international market for agricultural products. This resulted in the high vulnerability of surviving family farms, especially the smaller ones, which had somehow found ways to adapt their management in order to mitigate declining productivity. The fragile sustainability of these farms led to an unbalanced regional development, with the countryside depopulating and a growing number of rural people being gradually evicted to the suburbs of regional cities and becoming an acculturated proletariat.

Although Patagonian sheep farming has always been an all-man activity, families used to live in the estancias until the 1960s (the children however lived in boarding schools in town during the week and returned home over the weekends or only in summer if the town was far away). This explains why preferred sheep workers are single men and rural areas depopulate. Since in Patagonia the usual man/sheep ratio is $1 / 2000$, most ranches can be easily managed by one or two men, and very often one of them is actually the owner who lives in town where he has his main job.

Fortunately for the Patagonian economy the collapse of sheep ranching was offset by alternatives such as oil, gas and coal production, and tourism development. Although spatially very concentrated, these activities today support the territorial development as well as increasing metal mining and fishing. Urban centers are now interconnected by networks of roads, cables, pipelines and airports. Therefore, the Patagonian economy can well dispense with the rural sector (which currently only provides $5 \%$ of the regional gross domestic product). These changes concern the whole society, including traditional landowner families who have repositioned themselves in the reorganized social networks.

According to our scholar experience in sheep ranching in Patagonia and after discussing with the main stakeholders in the sheep industry there, we were led to rethink the future of Patagonian sheep ranching so as to construct several scenarios, among them three of the most contrasting ones caught our attention. The first one, termed "Laissez-faire", lets the present situation go on, which entails the development of land speculation on the rural areas and the accretion of bankrupted units into larger ranches, possibly only partly productive and owned by a few major national and international groups. The second scenario, termed "Park", is based on a decidedly scenic valorization of the rural landscape with the conversion into parks of vast portions of Patagonian ecosystems, once degraded by sheep. Current agrotourism in landscape-favored ranches might indicate an intermediate step in this direction. The third scenario, termed "Sheep", explores the revival of the

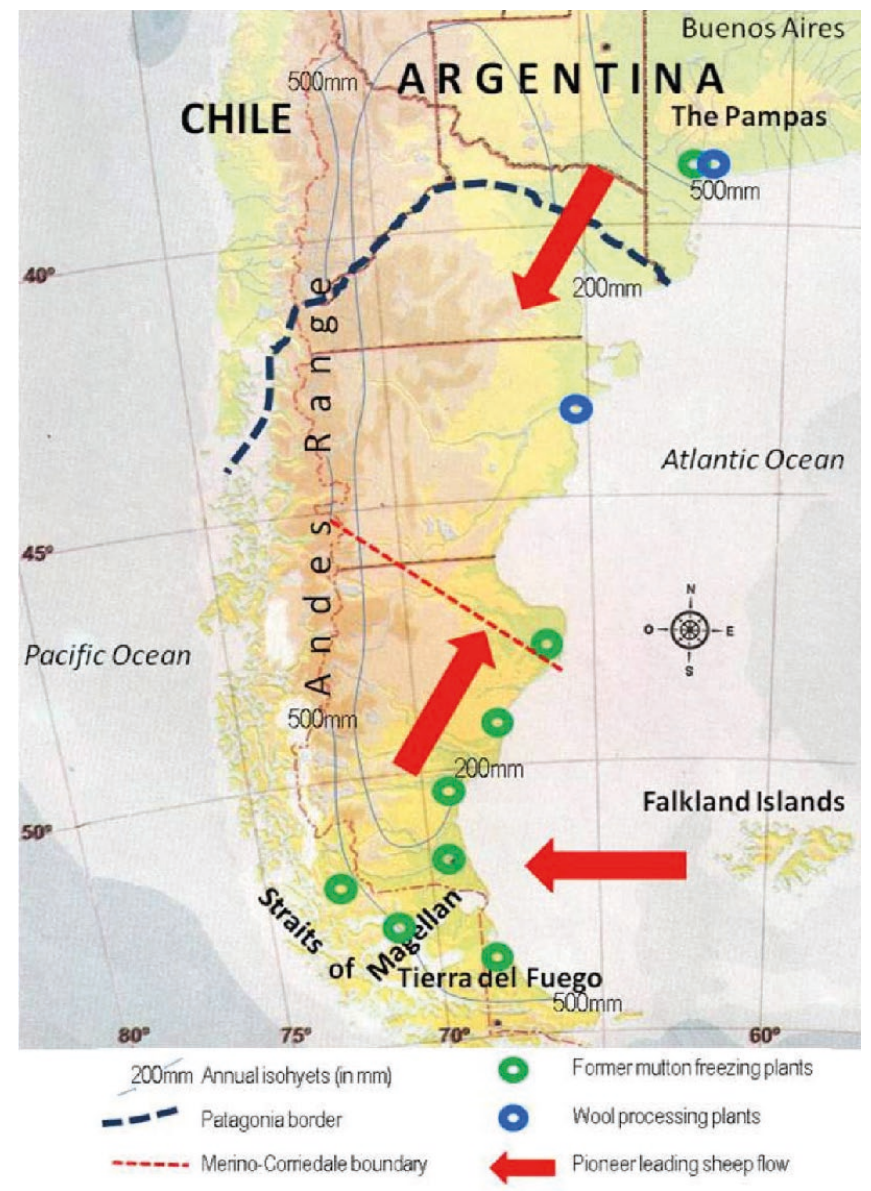

Figure 1: Map of Argentina showing the Corriedale-Merinos sheep border. 
sheep-breeding vocation in Patagonia with the restarting of family businesses based on sustainable socio-technological systems that require human and financial resources through public policies (possibly derived from the wealth of the subsoil). The current devolution of large spans of land to Native American communities could contribute to this pastoral perspective but a general zoning system based on land use alternatives would be strongly needed.

\section{DISCUSSION}

As stated above, the collapse of the sheep farming industry in Patagonia allows us to call it "restarting the system" from 2000 on. Nevertheless, according to current trends the most likely future of Patagonian sheep farming may emerge from the present scenarios sketched hereafter.

\section{Laissez-faire}

The very name of the Laissez-faire scenario suggests that it would mean a kind of "agrarian inertia", i.e. the continuation of the general declining trend of wool and mutton production with the laws of the market acting freely in a weakened economy. In this scenario it is possible to imagine a greater concentration of land tenure with the creation of vast ranches of several tens or even hundreds of thousands of hectares. Without surprise, winners would rarely be people with sheep breeding tradition or knowledge, but rather investors, who often are not even from the region.

Mining, from the very simple stone quarry to the sophisticated uranium extraction or polymetallic mega exploitations, will always be a real threat to unsustainable ranches located in exposed-bedrock areas, whereas those in sedimentary tablelands are threatened by oil exploration and exploitation. Regardless of the type of mining involved, some ranches located next to the deposits are already finding a new source of income by providing services to miners.

As mentioned above no alternative activities are needed to quit sheep farming: many ranches that became unsustainable were simply abandoned by their owners, the sheep sold and gates padlocked. Along with social issues, this generates ecological problems such as the proliferation of predators like pumas or foxes that attack the remaining flocks next door (Novaro and Walker, 2005).

There may be conflicts to manage on land ownership between large companies, small farmers, and Native American communities that could claim their so-called ancestral lands. There will necessarily be a deep urban-rural imbalance as this is already observed today.

\section{Park}

The Park scenario would boost the tourism economy, in line with the adventurous and ecological side of Patagonia as a trademark and would build on a cultural, environmental, and sustainable development foundation. Agrotourism is already a financial input to an ever growing number of ranches located in scenic areas. The website www.estanciasdesantacruz.com is just an example of the vitality of this initiative. Of course, sheep farming and the traditions related to it are carefully-preserved tourist attractions, especially in ranches less favored by scenic beauty or history.

In this scenario, sheep adopt the role of ecosystem gardeners in largely under stocked paddocks, where they can eventually coexist with guanacos and rheas. These non-domestic species are no longer seen as competitors of sheep but as a natural attraction in the park.
About $95 \%$ of Argentine Patagonian land is private property, which explains why the park scenario has already started in private ranches, even if in some cases public reserves have been created too. Pushing this scenario to the extreme, one could imagine an active government commitment in creating national parks (if the area is scenic or worthy of preservation from a scientific point of view) or just national reserves in less favored areas. However, the cost would be high because of the expropriations needed. Arguably the funds collected from mining in other areas, from the fishing industry or from the tourist trade itself could be used to this end.

National reserves in currently unused spaces occupy vast areas in Chilean Patagonia, but are void lands, never occupied before. In Argentina, national reserves in previously grazed rangelands would mean the utter recognition of the failure of sheep farming in colonizing Patagonia. Moreover, mining or great infrastructure works are not welcome in this conception of regional land use, even at current public opinion level. "No dams in Patagonia" and "No to mining" are frequently tagged on Patagonian walls.

\section{Sheep}

To recover Patagonia's sheep-breeding vocation might be the lesser risk from a political, economical and social point of view. Considering the depth of the current depression, sheep revival is a huge task which would require the joint involvement of ranchers and government. Actually, both have recently taken some interesting initiatives; they tend to consider wool and mutton as specialties rather than commodities as it was the case until recently.

Even though diverse official and private efforts to raise production quality start to bear fruit, much remains to be done. Public institutions and private organizations promote shifting to eco- or organic-labeled sheep products which are paid at much higher prices in the market. For instance, the organic-certified wool by the Organización Internacional Agropecuaria brings in 12-15\% more than non-labeled wool, bridging to some extent the sheep and park scenarios. Another example of converging scenarios is the synergy between local sheep farming-oriented organizations such as OVIS $21^{5}$ and international boards such as The Nature Conservancy, which promotes the conservative management of rangelands reserved to sheep in Patagonia that could contribute to improve the landscape ${ }^{6}$.

Agronomic constraints however seem to restrict these encouraging views to favorable areas while condemning others to greater efforts to overcome their geographic limitations. The aqueduct of Trelew-Uzcudun, built by ranch owners in eastern Chubut, is a good example of a private associative initiative to get over production difficulties. On the government side, production credits targeted to specific geographical areas should be preferred to widespread subsidies and compensations. Besides, official technical agencies such as the Instituto Nacional de Tecnología Agropecuaria have active responsibility in improving the production chain both upstream and downstream from the breeding level, with the establishment of sustainable management of rangelands. However, it is suggested that measures to restore and protect Patagonian ecosystems would gain greater acceptance if local producers were seen as equals in the conservation and development process. This could be achieved by replacing the traditional top-down models of policy design by implementing measures based on genuine consultation and participatory community-based approaches to natural resource management (Aagesen, 2000). Table I shows a simplified version of a SWOT (Strengths - Weaknesses - Opportunities Threats) matrix that summarizes what has been stated above.

5. www.OVIS21.com

6. www.nature.org/ourinitiatives/regions/southamerica/argentina/ 


\section{Table I}

SWOT matrix of the sketched scenarios for the future of sheep farming in Argentine Patagonia

\begin{tabular}{|c|c|c|c|c|}
\hline & Strengths & Weaknesses & Opportunities & Threats \\
\hline Laissez-faire & $\begin{array}{l}\text { Currently in force } \\
\text { Free initiative } \\
\text { Ubiquity }\end{array}$ & $\begin{array}{l}\text { Individualism } \\
\text { Imbalances generated } \\
\text { (economy, demography) } \\
\text { Labor scarcity }\end{array}$ & $\begin{array}{l}\text { Wide reaching } \\
\text { Technical support } \\
\text { Services provided }\end{array}$ & $\begin{array}{l}\text { Mining } \\
\text { Land hoarding } \\
\text { Depopulation } \\
\text { Land use conflicts }\end{array}$ \\
\hline Park & $\begin{array}{l}\text { Ecological trademark } \\
\text { International support }\end{array}$ & $\begin{array}{l}\text { Some expropriation needed } \\
\text { Restricted diffusion } \\
\text { Predator } \\
\text { Overpopulation }\end{array}$ & $\begin{array}{l}\text { Reassess native culture } \\
\text { History rescue }\end{array}$ & $\begin{array}{l}\text { "For export" stereotyping } \\
\text { Excessive openness to } \\
\text { the outside world }\end{array}$ \\
\hline Sheep & $\begin{array}{l}\text { International market assured } \\
\text { Regional identity preserved }\end{array}$ & $\begin{array}{l}\text { Some areas excluded } \\
\text { Restricted diffusion } \\
\text { Big investments }\end{array}$ & $\begin{array}{l}\text { New regional productions } \\
\text { Widen participation }\end{array}$ & $\begin{array}{l}\text { Separatism } \\
\text { Native claims }\end{array}$ \\
\hline
\end{tabular}

\section{CONCLUSION}

Sheep farming in Patagonia was at its lowest around the turn of last century, closing a cycle started one hundred years earlier, whose heyday (in stock) was reached in about 1950. The depth of the fall was enough to trigger some healthy reactions about how the future of the activity and therefore the future of the region should be, since sheep farming is the most widespread land use in Patagonia and deeply anchored in the regional identity (Coronato, 2010).

In recent years Patagonia's sheep stock has been increasing because of higher international wool prices, favorable domestic currency policies and the adoption of improved production technologies. Even so, this trend is expected to have reached its peak (Villagra et al., 2010) and a generalized recovery of the sheep-breeding industry seems unlikely.

Therefore, no future trend clearly stands out and we believe that any of the three scenarios described above could eventually prevail in the next decades. The more probable future of the Patagonian sheep industry would be a mixed scenario, not only in the involvement of the concerned actors but especially from a geographic standpoint. We believe that a regional land use plan is greatly needed to carry out zoning so as to define (on paper and in government policies) areas where one of the three scenarios should prevail, or at least, areas in which sheep ranching is no longer sustainable. As Noy-Meir (1995) clearly states: "Livestock production from rangeland is now feasible and sustainable only in certain parts of Patagonia; while in other parts there are no feasible solutions or opportunities for either maintaining it, or for re-establishing sustainable production."

Patagonia is large enough to enclose i) areas where no changes to the present situation would be introduced, ii) areas in which scenery or historical facts would justify their conversion into parks or reserves if they are too degraded (and be eventually sacrificed to mining), and iii) areas whose agronomic conditions are good enough to secure a sustainable (and improved) sheep farming system, producing high-quality mutton and wool.

\section{REFERENCES}

Aagesen D., 2000. Crisis and conservation at the end of the world: sheep ranching in Argentine Patagonia. Environ. Conserv., 27 (2): 208-215

Ares J., 2006. Systems valuing of natural capital and investment in extensive pastoral systems: Lessons from the Patagonian case. Ecol. Econ., 62 (1): 162-173

Cibils A., Borrelli P., 2005. Grasslands of Patagonia. In: Grasslands of the world; Plant production and protection (Eds. Suttie J., Reynolds S., Batello C.). FAO, Rome, Italy (Ser. No 34)

Coronato F., 2010. Moutons et colons en Patagonie. Editions universitaires européennes, Sarrebruck, Allemagne, $318 \mathrm{p}$.

Defossé G., Robberecht R., 1987. Patagonia : Range management at the end of the world. Rangelands, 9 (3): 106-109

Del Valle H., Elissalde N., Gagliardini A., Milovich J., 1997. Desertification assessment and mapping in the arid and semi-arid regions of Patagonia (Argentina). Desertification Control Bull., 31: 6-11

Golluscio R., Deregibus A., Paruelo J., 1998. Sustainability and range management in the Patagonian steppes. Ecol. Austral, 8: 265-284

Nouzeilles G., 1999. Patagonia as borderland: nature, culture, and the idea of the State. J. Latin Am. Cult. Stud., 8 (1): 35-48

Novaro A., Walker S., 2005. Human-induced changes: the effect of top-carnivores on biodiversity in the Patagonian steppes. In: Large carnivores and the conservation of biodiversity (Eds. Ray J., Redford K., Steneck R., Berger J.). Island Press, Washington DC, USA, p. 268-288

Noy-Meir I., 1995. Sustainability and management of natural resources in Patagonia. In: Proc. Int. Workshop on Plant Genetic resources, desertification and sustainability (Eds. Montes L., Oliva G.), INTA Rio Gallegos, Nov. 1994, 238 p.

Villagra S., Giraudo C., Mueller J., 2010. Merino productions systems in Patagonia. In: 8th World Merino Conf., Rambouillet, France, 3-5 May 2010 


\section{Résumé}

Coronato F., Fasioli E., Schweitzer A., Tourrand J.-F. Repenser le rôle des moutons dans le développement local de la Patagonie en Argentine

Les parcours de Patagonie sont les plus au sud de la planète et parmi les derniers à se consacrer à l'élevage. La filière ovine s'y est installée depuis seulement 100-120 ans et a prospéré jusqu'à la crise mondiale de 1930, provoquant la colonisation rapide de parcours de productivité diverse. Mise à part la diversité agronomique, les risques naturels comme la sécheresse ou les fortes chutes de neige, associés aux aléas des politiques économiques ont toujours fait de l'élevage ovin en Patagonie une activité très incertaine. Ainsi, cet élevage a peu à peu perdu son rôle d'activité socio-économique principale face à l'exploitation de pétrole ou de gaz, la pêche, et dernièrement le tourisme. La situation $s^{\prime}$ est considérablement aggravée pendant le dernier quart du XXe siècle ; la participation du secteur agricole dans le produit intérieur brut régional n'atteint pas aujourd'hui $5 \%$. Cependant, l'élevage ovin est la seule activité qui assure l'occupation, même faible, de I'ensemble de la région ; cette activité pionnière permet au mouton de conserver un rôle important à jouer dans l'identité de la Patagonie. Ainsi, nous estimons que le mouton, tant par la filière laine que par la filière viande, continue $d^{\prime}$ avoir sa place dans l'avenir de la région. Nous soutenons que l'avenir du mouton en Patagonie serait dans I'adoption de I'un des trois scénarios que nous appelons "laisser-faire », "parc » et « mouton » en fonction de l'intensité des interventions et des fonds mobilisés. Les trois scénarios pourraient coexister mais la durabilité sur le long terme aurait le dernier mot.

Mots-clés: ovin, utilisation des terres, parcours, désertification, aptitude à coloniser, Argentine

\section{Resumen}

Coronato F., Fasioli E., Schweitzer A., Tourrand J.-F. Reevaluación del papel de la oveja en el desarrollo local en Patagonia, Argentina

La Patagonia posee los pastizales más australes del mundo y son parte de los últimos dedicados a la agricultura. La cría comercial de ovejas en la zona se inició sólo hace 100-120 años y prosperó hasta la crisis mundial de 1930, provocando la rápida colonización de praderas de diversa productividad. Además de esta diversidad agronómica, los riesgos naturales, como las sequías o las fuertes nevadas, asociados a los caprichos de las políticas económicas, siempre han hecho de la cría de ovejas en la Patagonia una actividad muy incierta. En consecuencia, las ovejas perdieron terreno gradualmente como principal actividad socioeconómica, frente a la producción de gas y petróleo, la pesca, y últimamente el turismo. Las cosas empeoraron durante el último cuarto del siglo 20, hasta el punto en que hoy la contribución de la agricultura al producto interno bruto regional es menos del 5\%. Sin embargo, la cría de ovejas es la única actividad que asegura la ocupación, aunque escasa, de la región y, debido a su carácter pionero, sigue desempeñando un papel importante en la identidad de la Patagonia. Por lo tanto, creemos que la carne de cordero y la producción de lana, todavía tienen un papel que desempeñar en el futuro de la región, aunque argumentamos que esta posibilidad debe incluir uno de los tres escenarios que hemos Ilamado de «laissez-faire», «estacionario» y «ovejas», según la intensidad decisional implicada y los fondos necesarios. Los tres escenarios podrían eventualmente coexistir, pero la sostenibilidad a largo plazo tendrá la última palabra.

Palabras clave: ovino, utilización de la tierra, tierra de pastos, desertificación, aptitud colonizadora, Argentina 
